\title{
Izabela Oleksiewicz, Marek Górka, Bezpieczeństwo pozamilitarne i quasi-militarne Europy Zachodniej, Adam Marszałek Publishing House, Toruń 2019, pp. 177
}

\author{
Lech Wyszczelski
}

Security was recognized as a scientific discipline only in the first half of the 1990s, replacing the previous discipline of military science. Initially, it was represented mainly by military scientists, but rather quickly expanded by its development also in civil education (especially as secreted didactic disciplines). Then two scientific disciplines were extracted from it: security and defense (which I considered as an artificial division) which eventually were re-constituted as one discipline of "security". It included various specialties (often on a sly substantive basis) among which national security was the most popular. I participated in these processes until 2002 as a Professor at the Academy of National Defence (AON) and I know the backstage of these events.

\section{Presentation of the reviewed book}

It is written by Assoc. Prof. Izabela Oleksiewicz from Rzeszów University of Technology and Marek Górka, PhD, Assistant Professor at the Koszalin University of
Technology. This is already a confirmation of how wide is the circle of people dealing with the subject of different dimensions of security.

As for the collective work, the design of this book is quite astonishing and unusual. It does not distinguish the authors of its particular parts. Did authors employed in very distant universities write all parts together? One can adopt such a version. In addition, a division into non-military and quasi-military threats was introduced. The former generally boil down to political, ideological, economic rivalries, as the struggle of individual civilizations. Why was the theory of the "waves of civilization" created by Alvin Toffler omitted? The latter is the forms of competition. Among them, the authors mention information wars (why they do not consider ideological struggle?), cyberterrorism, personal terrorism and the problem of migration. I consider this to be a selective treatment of this division. I see a completely different one. It includes, for example, new generation wars, hybrid wars, Muslim wars 
(using religion and ideology), wars among societies and cultural conditions of wars. They are characterized by considering both certain possibilities of using combat means of struggle and, above all, nonmilitary actions. Of course, this is one of the promoted divisions of the wars of the future, but it is popular not only among military theorists but also those specializing in the analysis of non-military threats.

The book consists of an introduction, three chapters and bibliography, and other additional elements. All in all, it is not too extensive position in terms of volume.

The initial effort was to demonstrate the importance of security for the functioning of society in its various dimensions. However, there was no provision of the most important thing, namely both the definition of the term 'safety' (which is differently defined in the body of literature) and, in particular, the definition of 'non-military security' which is the content of that publication. First of all, it is advisable to recall in this area numerous methodological achievements of the scientific staff of the former AON (including Professors Maciej Marszałek and Bogdan Szulc). I would also advise the authors to read an interesting publication in this area published by Adam Marszałek Publishing House $^{1}$. I could name a lot of other nonlitary security publications.
The first chapter "The Conditions of Non-Military and Quasi-Military Security in Western Europe" is an interesting introduction to the subject matter of the book. It is also, as it turns out, the most interesting in the whole work. It lacks - in my opinion - admittedly general information about this type of security in the international scale. Meanwhile, it now poses a greater threat to world security than a real military threat. That is why, I would recommend in the next edition of this publication references to the valuable thoughts of Alvin Toffler consisted in his books Shock of the Future and The Third Wave or written jointly with Heidi Toffler War and Antiwar; Samuel Phillip Huntington's Clash of Civilizations and the New World Order, or Alexander Gilewicz Dugin's Osnowy geopolityki. Geopoliticzeje bubuszczeje Rossij (certainly a publication that is more famous in the world and, moreover, its certain indications are realized today rather than those from the book "Geopolitics" written by Carlo Jean mentioned by the authors). This is just a suggestion to broaden the scope of authors' considerations.

According to the reviewer, what is the most interesting research thread of this team? The statements that the world's leading country, the US, is imposing its vision of ensuring global security. I therefore fully

1 S. Sulowski (Ed.), Tożsamość nauk o bezpieczeństwie. O rozwoju badań i postulacie interdyscyplinarności w naukach o bezpieczeństwie, Toruń 2015. 
agree with the authors' views on the role of the United States, where there is a feeling that the US have the most important right 'to freedom to make decisions in the name of the national interest' and to promote globally the so-called American values, which led "to the complete collapse of the global humanitarian aid system under the auspices of the United Nations". It is not the international community, but the US, that has a patent to determine the scale of this danger and, above all, the right to use all means - including military ones - to enforce respect for their vision of global security and order. Similarly, I agree with the fact that such a thinking has led to the promotion of the so-called "preventive diplomacy". In 1996, analysts of this state promoted the term "just war" which is included in the country's security doctrine. It was recognized that the "extent to which our own armed forces are involved in peacekeeping missions depends to a large extent on the shape of US national interests", which is considered to be the beginning of an era of "one-dimensional world", making radical changes to the global security system. Thus, the country attributed itself the role of "gendarme" guarding this security, both at the level of military and non-military security. As the mistake of this superpower, together with the powers of Western Europe, can be regarded - in my opinion - political and military involvement in the civil war in the countries created after the collapse of Yugoslavia. I say that, on this occasion, Western Europe has "given" itself a habitat on the continent for the fore of radical Islamism and the associated "hatchery" of local terrorism? This is true, but it is not supported in this case by the fact that the major countries of Western Europe have also adhered to the US non-military security strategy. Can we therefore agree with prof. Ryszard Zięba's quoted reference that the European Union "deserved the good name of a peaceful international actor" Would not London, Paris, partially Berlin and Rome supported American aggression leading to war with Iraq (the threat of the country's use of chemical weapons, which actually was not in the country possession at that time), including Operation Desert Storm or American intervention in Afghanistan? In this regard, it sees the causes of the weaknesses highlighted in the European Union and its crisis. The period of Donald Trump's presidency has demonstrated this emphaly. He takes various steps to weaken the political and economic position of the European Union. That's my opinion too. In general, I consider this chapter to be the most interesting in the reviewed book.

Chapter two, on the other hand, corresponds quite loosely with the subject of the book. It is announced even in its title: "Selected paradigms of the European Union and the organization of the North Atlantic Pact". It has the character of a political debate, quite loosely entliving 
to non-military security or even quasimilitary one. The matter of fact is that the military security of the Western world is primarily based on the US capabilities as NATO's main state. However, the European Union, as an organization with has political and economic objectives, cannot be required to play a similar role to NATO in security matters. It seems that aggressive US policy - particularly under Trump's presidency - is the cause of conflicts rather than harmonious cooperation between the Western world. Against the background of general reservations about the need of including this chapter in this book, I can only see the section entitled "The European Union in international politics" as truly needed, though it counts barely two pages.

The third chapter entitled "Institutionalization of non-military security in Western Europe" makes much better impression. A lot of interesting information result from the activities of the Council of Europe in the face of cybercrime, including the "Council of Europe Convention on Cybercrime" adopted by this entity. However, it is debatable to include another chapter on the role of the UN in the fight against crime. This is not a European body. I recommend reading the section on the European Union's action against terrorism and cyberterrorism.

It is true that terrorism and cyberterrorism are among the main threats to the modern world at the stage of non-military attempts to impose one's own will on the adversary. But I think that not only them. Did the authors not see the threats described as hybrid, including the role of information war? Today, they are regarded by many as the greatest threats to the world peace. Many experiences have been brought by the involvement of a coalition of Western countries, with the leading participation of the American army, in the war, first in Iraq in the last decade of the previous century, and then in the first decade of new century in Afghanistan. It can be considered that the myth promoted primarily by American theorists about the dominance of "technology" over "man" vanished. But, is it just this one?

In the early 1990s, Americans John Arquilla and David Ronfeldt predicted the rapid arrival of "cyber warfare". They argued that they were part of "IT wars". In 1993, they announced the theory of "network war" in the prestigious journal "Comparative Strategy". The term refers to a new theory of war or conflict, as they claimed, at the social level, in which resources are used below the threshold of regular war, as well as online forms of doctrines, organization, and communication. The developments of their thoughts were included in a publication from 1996 entitled The Advent of Netwar. In American theoretical reflection, the term "cyberwar" ("cyber warfare") is presented as a concept of struggle to incapacitate communication systems and other appa- 
ratus based on microprocessors. Theorists, but also the military practitioners of this country, dominate the considerations and practical preparations for such a war. Such considerations can be summarized with a conclusion that "cyberwar" is no longer just a theoretical concept. It also means practical solutions that may even lead to the creation of formations within the armed forces aimed at conducting such operations.

Finally, some notes to the bibliography. It confirms that the authors prefer a political approach to its presentation. They divided it into: $1 /$ legal files and documents, and
2/ literature (why not elaborations?). In the latter case, there is no division into compact and causal items. It is dominated by political studies, to a much lesser extent fitting directly to the discipline of safety.

Some critical remarks, in part, can be regarded as polemical, not depreciating this study. The reviewer's intention is not so much to discuss, but to indicate possible areas for the refinement of the subject matter or to show another worthy approaches to consider it. From this point, I recommend readers to familiarize themselves with this book. 